(c) American Dairy Science Association, 2005.

\title{
Effects of Flaxseed on Protein Requirements and N Excretion of Dairy Cows Fed Diets with Two Protein Concentrations*
}

\author{
H. V. Petit, ${ }^{1}$ M. Ivan, ${ }^{1}$ and P. S. Mir $^{2}$ \\ ${ }^{1}$ Dairy and Swine Research and Development Centre, Agriculture and Agri-Food Canada \\ Lennoxville, QC, Canada J1M 1 Z3 \\ ${ }^{2}$ Lethbridge Research Centre, Agriculture and Agri-Food Canada \\ Lethbridge, AB, Canada T1J 4B1
}

\begin{abstract}
Thirty-eight midlactating Holstein cows averaging $597 \mathrm{~kg}$ of body weight $(\mathrm{SD}=59)$ were used to determine the effects of dietary flaxseed on protein requirement and $\mathrm{N}$ excretion in urine and feces. Milk yield and composition, intake, and digestibility were also determined. Cows were allotted from wk 20 to 30 of lactation to 1 of 4 TMR containing 1) no flaxseed (control) and 16\% protein (MPC), 2) whole flaxseed and 16\% protein (MPF), 3) no flaxseed (control) and 18\% protein (HPC), and 4) whole flaxseed and 18\% protein (HPF). Cows fed high protein diets had greater feed intake than those fed medium protein diets ( $20.2 \mathrm{vs} .18 .4 \mathrm{~kg} / \mathrm{d})$, and cows fed no flaxseed had greater dry matter intake than those fed flaxseed (20.1 vs. $18.5 \mathrm{~kg} / \mathrm{d}$ ). Milk yield was lower for cows fed MPF $(20.3 \mathrm{~kg} / \mathrm{d})$ than for those fed HPC $(24.4 \mathrm{~kg} / \mathrm{d}), \operatorname{HPF}(24.9 \mathrm{~kg} / \mathrm{d})$, or MPC $(24.0 \mathrm{~kg} / \mathrm{d})$. Milk protein and lactose concentrations were similar for cows fed MPC and HPC, but flaxseed decreased milk protein concentration in cows fed MPF or HPF compared with cows fed the control diets. Milk fat concentration was similar in cows fed diets with or without flaxseed, but it was decreased by higher protein concentration. Digestibility was generally reduced when diets contained flaxseed and lower protein concentration. Dietary protein had no effect while dietary flaxseed increased fecal $\mathrm{N}$ excretion. Retention of $\mathrm{N}$ was lower in cows fed flaxseed compared with cows fed the control diets. Feeding flaxseed decreased milk concentrations of short- and medium-chain fatty acids and increased those of long-chain fatty acids. Flaxseed had no effect on the dietary requirement of $\mathrm{N}$ by midlactating dairy cows.
\end{abstract}

(Key words: dairy cow, flaxseed, protein, milk production)

Received October 19, 2004.

Accepted January 11, 2005.

Corresponding author: H. V. Petit; e-mail: petith@agr.gc.ca.

*Contributions number 849 from the Dairy and Swine Research and Development Centre and (387)05001 from the Lethbridge Research Centre.

\begin{abstract}
Abbreviation key: CLA = conjugated linoleic acids, $\mathbf{H P}=$ high protein, $\mathbf{H P C}=$ high protein control, $\mathbf{H P F}=$ high protein with flaxseed, MP = medium protein, MPC = medium protein control, MPF = medium protein with flaxseed.
\end{abstract}

\section{INTRODUCTION}

Postruminal supplementation with amino acids and proteins is known to increase milk and milk protein yields (Clark, 1975). According to Crawford and Hoover (1984), increased milk protein concentration for cows fed RUP (Vérité and Journet, 1977) is usually a result of greater ruminal bypass of protein, which increases amino acid availability for intestinal absorption. In addition, dietary vegetable oil has been shown to increase secretion and activity of pancreatic enzymes, enhancing digestion and absorption of proteins in the small intestine and associated efficiency of protein use (Mir et al., 2000). Therefore, increased amounts of dietary RUP and oil could improve the overall use of dietary protein, resulting in increased production of milk and its protein concentration.

Flaxseed is an excellent source of n-3 fatty acids, which are known to be anticarcinogenic, and which contribute to prevention of cardiovascular diseases and to improved vision (Wright et al., 1998). Flaxseed contains approximately $31 \%$ oil and $25 \%$ protein, and it has been shown to increase concentration and yield of milk protein compared with micronized soybeans or Ca-salts of palm oil when used in diets of dairy cows (Petit, 2002). Moreover, protein concentration in milk was greater in cows fed flaxseed compared with those fed sunflower seed (Petit, 2003). Flaxseed is smaller than sunflower seed, which might increase its rate of passage from the rumen resulting in increased supply of amino acids for synthesis of milk protein. According to Satter (1986), feeding cows low protein diets supplemented with a protein resistant to ruminal degradation may result in a flow of $\mathrm{N}$ to the small intestine that is similar to those of cows fed diets with higher concentration and degradability of protein if microbial protein synthesis 
Table 1. Composition of the silages.

\begin{tabular}{llc}
\hline & $\begin{array}{l}\text { Grass-alfalfa } \\
\text { silage }\end{array}$ & $\begin{array}{c}\text { Corn } \\
\text { silage }\end{array}$ \\
\hline Dry matter, \% & 31.1 & 39.1 \\
CP, \% of DM & 16.5 & 6.7 \\
ADF, \% of DM & 34.9 & 30.6 \\
NDF, \% of DM & 52.3 & 45.3 \\
Ca, \% of DM & 0.77 & 0.18 \\
P, \% of DM & 0.35 & 0.21 \\
\hline
\end{tabular}

is not affected. Moreover, dietary oil supplements of flaxseed (Ikwuegbu and Sutton, 1982) or sunflower seed (Ivan et al., 2001), or feeding of rolled sunflower seeds (Ivan et al., 2003) reduces rumen fauna, which might result in decreased requirements for dietary protein (Ivan et al., 2004). Reduction or elimination (defaunation) of rumen fauna is associated with decreases in ammonia concentration in rumen fluid and with increased amino acid (feed and bacterial origin) flow into the duodenum (Veira et al., 1983; Ivan et al., 1991). In fact, reduction in rumen fauna increased the yield of milk protein (Moate, 1989). Flaxseed could, therefore, contribute to increased flow of $\mathrm{N}$ to the small intestine because of its greater bypass of protein and of its effect on the ruminal protozoa population. The increased flow of $\mathrm{N}$ could decrease the requirement for dietary protein due to the associated improvement in the efficiency of dietary $\mathrm{N}$ use. This could lead to lesser $\mathrm{N}$ losses in feces and urine. Therefore, the objective of the present experiment was to determine effects of dietary flaxseed on the dietary protein requirement for milk production and composition and on $\mathrm{N}$ excretion in urine and feces of lactating dairy cows.

\section{MATERIALS AND METHODS}

The experiment was conducted at the Atlantic Dairy and Forage Institute of Fredericton Junction, New Brunswick, Canada, from June 2002 to February 2003. Twenty-six multiparous and 12 primiparous midlactating Holstein cows, averaging $597 \mathrm{~kg}$ of $\mathrm{BW}(\mathrm{SD}=59$ ), were used. The cows were blocked within parity for similar calving dates. The experiment was conducted from wk 20 to 30 of lactation. The cows were housed in tie stalls, fed individually, and milked twice daily at 0615 and $1530 \mathrm{~h}$. Milk production was recorded at every milking. Cows within blocks and within parity were assigned randomly to 1 of 4 dietary treatments based on a mixture of silages (Table 1). Two of the diets (Table 2 ) had a medium protein concentration (MP, 16\%) and 2 had a high protein concentration (HP, 18\%). Within each protein concentration, one diet was without flaxseed (control) and the other contained flaxseed at approximately $12 \%$ of the dietary DM. Flaxseed replaced a part of the concentrate (mainly barley grain) in the 2 control diets. Therefore, the 4 diets (treatments) were 1) medium protein control without flaxseed (MPC), 2) medium protein with flaxseed (MPF), 3) high protein control without flaxseed (HPC), and 4) high protein with flaxseed (HPF). There were 10, 10, 9, and 9 cows on treatments MPC, MPF, HPC, and HPF, respectively. All diets were formulated to meet requirements for cows that had a mean BW of $600 \mathrm{~kg}$ and produced $30 \mathrm{~kg} / \mathrm{d}$ of milk with $3.85 \%$ fat (NRC, 2001) for an expected daily DMI of around $22.8 \mathrm{~kg}$.

Milk samples were obtained weekly from each cow for 2 consecutive milkings and were analyzed separately to determine milk composition. Body weight of cows was determined weekly. Feed consumption was recorded daily. The cows were fed twice daily at 0600 and 1400 $\mathrm{h}$ for $10 \%$ orts. The TMR were sampled weekly, frozen at $-15^{\circ} \mathrm{C}$, composited on a 4 -wk basis, and kept frozen for further analyses.

Total feces, urine, and milk were collected from all cows for $7 \mathrm{~d}$ during wk 8 of the experiment. Feces were collected from a rubber mat placed behind the animals and stored in plastic containers. Daily feces were weighed and mixed thoroughly. A $10 \%$ subsample was taken daily and stored at $-15^{\circ} \mathrm{C}$ for subsequent drying at $55^{\circ} \mathrm{C}$. Total urine was collected in stainless steel containers via a Gooch tube (BF Goodrich Co., Kitchener, ON, Canada) attached to the cow with a nylon netting covered with neoprene (Spall Bowan Ltd., Guelph, ON, Canada) affixed to the vulva. Urine was acidified daily with $100 \mathrm{~mL}$ of $10 \mathrm{~N} \mathrm{H}_{2} \mathrm{SO}_{4}$. Seven daily subsamples (1\%) were accumulated and stored frozen $-15^{\circ} \mathrm{C}$ until analysis. Milk samples were obtained from each cow for 14 consecutive milkings and were analyzed for $\mathrm{N}$ to calculate $\mathrm{N}$ balance.

Rumen fluid samples ( $300 \mathrm{~mL}$ ) were collected on $\mathrm{d} 2$ and 4 ( $2 \mathrm{~h}$ after the morning feeding) of wk 0 and 10 of the experiment using an esophageal tube. A part $(100 \mathrm{~mL})$ of each sample was strained through 1 layer of cheesecloth for protozoal count. The remainder of the sample was strained through 2 layers of cheesecloth for chemical analyses. A 5-mL portion of the rumen fluid strained through 1 layer of cheesecloth was immediately mixed with $5 \mathrm{~mL}$ of methyl green-formalin-saline and stored in darkness until protozoal counts. For VFA and lactate analysis, $5 \mathrm{~mL}$ of rumen fluid strained through 2 layers of cheesecloth was mixed with $1 \mathrm{~mL}$ of chilled $25 \%$ meta-phosphoric acid $\left(\mathrm{H}_{2} \mathrm{PO}_{4}\right)$ and centrifuged at $20,000 \times g$ for $20 \mathrm{~min}$. For ammonia $\mathrm{N}$ and soluble $\mathrm{N}$ analysis, $15 \mathrm{~mL}$ of rumen fluid strained through 2 layers of cheesecloth was mixed with $1.5 \mathrm{~mL}$ of chilled $65 \%$ TCA to acidify the sample and precipitate protein. The samples were kept on ice, centrifuged at $20,000 \times g$ and $4^{\circ} \mathrm{C}$ for $20 \mathrm{~min}$, and divided into 2 parts 
Table 2. Composition of experimental diets. ${ }^{1}$

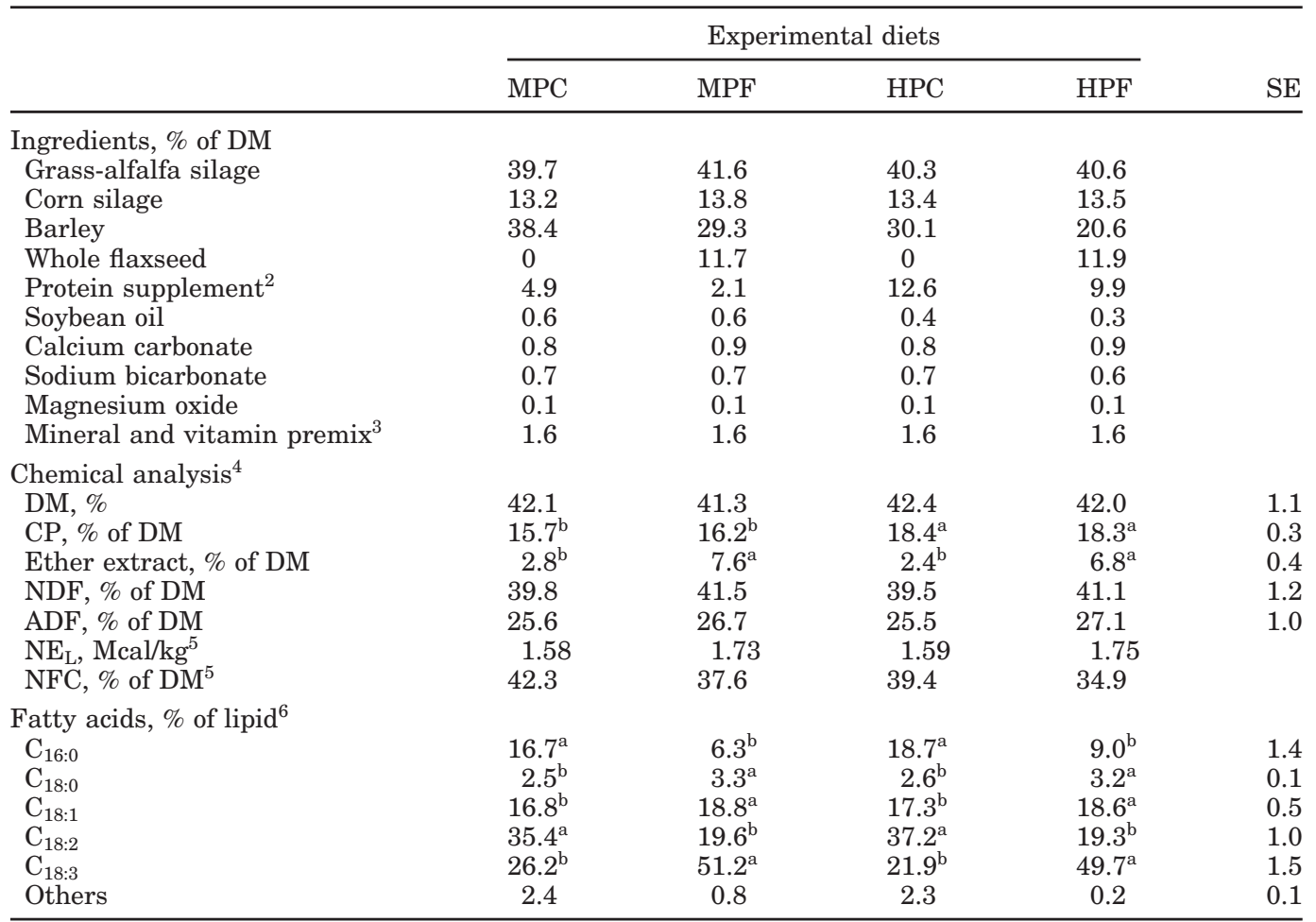

${ }^{\mathrm{a}, \mathrm{b}}$ Means within rows with different superscripts differ $(P<0.05)$.

${ }^{1} \mathrm{MPC}=$ Medium protein $(16 \%)$ control; $\mathrm{MPF}=$ medium protein $(16 \%)$ with flaxseed $\mathrm{HPC}=$ high protein $(18 \%)$ control; HPF $=$ high protein $(18 \%)$ with flaxseed. Least squares means with pooled SE.

${ }^{2}$ Contained (as-fed basis): $46 \%$ soybean meal (48\% CP), $21.9 \%$ canola meal, $17.0 \%$ corn gluten meal, $0.5 \%$ tallow, $5.2 \%$ calcium carbonate, $4.9 \%$ salt, $3.1 \%$ dicalcium phosphate, and $1.4 \%$ magnesium oxide.

${ }^{3}$ Premix contained (as-fed basis) $270,000 \mathrm{IU}$ of vitamin A/kg, 80,000 IU of vitamin D/kg, $1200 \mathrm{IU}$ of vitamin $\mathrm{E} / \mathrm{kg}, 20.0 \% \mathrm{Ca}, 6.4 \% \mathrm{P}, 3.8 \% \mathrm{Mg}, 7.2 \% \mathrm{Na}, 0.7 \% \mathrm{~S}, 0.7 ; 12 \mathrm{mg} / \mathrm{kg}$ of Se, $4000 \mathrm{mg} / \mathrm{kg}$ of Zn, $80 \mathrm{mg} / \mathrm{kg}$ of I, $20 \mathrm{mg} / \mathrm{kg}$ of Co, $2000 \mathrm{mg} / \mathrm{kg}$ of Mn, $600 \mathrm{mg} / \mathrm{kg}$ of Cu, $3000 \mathrm{mg} / \mathrm{kg}$ of Fe.

${ }^{4}$ Mean of 10 monthly samples prepared by compositing weekly samples.

${ }^{5}$ Calculated using published values of feed ingredients (NRC, 2001).

${ }^{6}$ Mean of 7 daily samples collected during the digestibility trial.

for analysis of ammonia $\mathrm{N}$ and soluble $\mathrm{N}$. All samples, except those for protozoal counts, were stored frozen $-15^{\circ} \mathrm{C}$ until chemically analyzed.

\section{Chemical Analyses}

Dry matter of total mixed diets, silages, and feces was determined by drying at $100^{\circ} \mathrm{C}$ for $48 \mathrm{~h}$. Total $\mathrm{N}$ determination in silages, diets, and feces was by the Kjeldahl method (AOAC, 1990). Concentrations of NDF and ADF in silages, diets, and feces were measured according to the nonsequential procedures of Van Soest et al. (1991). Feed was characterized separately during wk 7 and 8 for intake and digestibility calculations. Nitrogen, fat, and lactose in milk were determined by infrared spectroscopy (AOAC, 1990; Bentley 2000; Bentley Instrument, Inc., Chaska, MN), except for $\mathrm{N}$ in milk samples collected during the digestion trial, which was analyzed by the Kjeldahl method (AOAC, 1990). Ether extraction of diet samples was conducted with a Soxlec system HT6 apparatus (Tecator, Fisher Scientific, Montreal, QC, Canada) according to method no. 7.060 (AOAC, 1990).

Milk fatty acid composition and fat concentration were determined on samples collected on wk 0,4 , and 8 of the experiment. Fat was extracted from milk samples using a method adapted from Jiang et al. (1996). Extracted lipid samples were methylated (Lock and Garnsworthy, 2002) and fatty acid methyl esters were separated on an HP 5890 GLC fitted with an HP autosampler (model \#18596C, HP 7673 injector, HewlettPackard, Ltd., Mississauga, ON, Canada) and a flame ionization detector. Hewlett Packard 3365 Chemstation software was used for chromatogram integration and analysis. Samples were introduced onto a $100-\mathrm{m} \mathrm{Su}-$ pelco (Oakville, ON, Canada) SP-2560 column (part 
number 24056) via $1-\mu \mathrm{L}$ splitless injections. The temperature program was as follows: level $1,120^{\circ} \mathrm{C}$ held for $15 \mathrm{~min}$; level 2,120 to $160^{\circ} \mathrm{C}$ at $5.0^{\circ} \mathrm{C} / \mathrm{min}$ increments, then held for $15 \mathrm{~min}$; level 3,160 to $240^{\circ} \mathrm{C}$ at $4^{\circ} \mathrm{C} / \mathrm{min}$ increments, then held for $30 \mathrm{~min}$. Injector temperature was set at $220^{\circ} \mathrm{C}$, and the detector was set at $275^{\circ} \mathrm{C}$. Column head pressure was set at $206 \mathrm{kPa}$. A 2-mm i.d. splitless injection sleeve (Chromatographic Specialties Inc., Brockville, ON, Canada) was used for all injections. Gas flow rates were: helium (carrier) 1.7 $\mathrm{mL} / \mathrm{min}$, helium (make up) $29 \mathrm{~mL} / \mathrm{min}$, compressed air $320 \mathrm{~mL} / \mathrm{min}$, and hydrogen $34 \mathrm{~mL} / \mathrm{min}$.

Ciliate protozoa were counted using a Neubauer improved bright-line counting cell ( $0.1 \mathrm{~mm}$ depth, Hausser Scientific, Horsham, PA) in rumen fluid samples preserved with methyl green-formalin-saline solution (Ogimoto and Imai, 1981). Each sample was counted twice, and if the coefficient of variation of the 2 counts was greater than $10 \%$, the counts were repeated. During each counting, the numbers of different genera (Ogimoto and Imai, 1981) in the population were recorded and grouped as Entodinium spp., Holotrichs (Isotricha and Dasytricha spp.), and cellulolytic protozoa (Polyplastron, Diplodinium, Ostracodinium, and Enoplastron spp.). Frozen rumen fluid samples were thawed and centrifuged at $20,000 \times g$ for $10 \mathrm{~min}$, then analyzed for VFA using a Varian Star 3400 CX GLC (Varian Associates, Palo Alto, CA) equipped with an 8200 autosampler and a fused silica column (DB-FFAP, $15 \mathrm{~m}$ $\times 0.25 \mathrm{~mm}$ i.d., J \& W Scientific, Folsom, CA). Ammonia $\mathrm{N}$ was analyzed in the same samples by the phenolhypochlorite reaction (Weatherburn, 1967).

\section{Statistical Analyses}

Data were assessed for normality and a logarithmic transformation was used before the analysis of protozoal counts. All results were subjected to least squares ANOVA for a randomized complete block design; data were analyzed using a $2 \times 2$ factorial arrangement of treatments using the GLM procedure of SAS (SAS Institute, 2000). Data on diet composition, initial and final $\mathrm{BW}$, change in BW, and digestibility were analyzed as a randomized block design, and block and treatment were the main sources of variation. Data on milk production, DMI, BW, and rumen fluid composition were analyzed as repeated measurements using PROC MIXED of SAS, and as mean values for the 10-wk experiment when there was no interaction between week and treatment $(P>0.1)$. Differential temporal responses to dietary treatments were further examined using the SLICE option of the MIXED procedure. Treatment sum of squares were partitioned to provide orthogonal contrasts and compared: 1) flaxseed vs. no flaxseed, 2) high vs. medium protein concentration, and 3) the interaction between flaxseed and protein concentration.

\section{RESULTS AND DISCUSSION}

All diets had similar concentrations of $\mathrm{DM}, \mathrm{ADF}$, and NDF, and protein concentrations were within 0.4 percentage units from the expected values (Table 2). Ether extract concentration was lower $(P<0.05)$ for diets without flaxseed compared with those with flaxseed. Concentration of $\mathrm{C}_{18: 3}$ was higher in diets with flaxseed, which would reflect the greater $\mathrm{C}_{18: 3}$ concentration in flaxseed than in the feed ingredients used in the other diets.

There was an interaction between treatment and experimental week for DMI (Figure 1) due to lower intake for cows fed MP compared with those fed HP diets, and for those fed flaxseed compared with those fed no flaxseed (control) on wk 9 and 10 of the experiment. On average for the 10 -wk period, when DMI was expressed in kilograms of DM per day, cows fed HP diets had greater feed intake than those fed MP diets, and cows fed no flaxseed had greater DMI than those fed flaxseed (Table 3). Similarly, there was a trend $(P=0.11$ and 0.13 , respectively) for lower DMI, expressed as a percentage of BW, when cows were fed flaxseed compared with those fed no flaxseed and for cows fed HP compared with MP diets. Whole flaxseed is readily accepted by early-lactating cows and has no negative effect on DMI (Petit, 2002), but the effect on DMI of midlactating cows is unknown. However, the magnitude of the decrease in DMI when feeding supplemental fat tends to be greater for cows in mid than in early lactation (Onetti and Grummer, 2004) and feeding a relatively large amount of fat generally decreases DMI of dairy cows although oilseeds have a less consistent effect on DMI (Allen, 2002).

Milk yield (Table 3 ) tended $(P=0.06)$ to be lower for cows fed the MPF diet $(20.3 \mathrm{~kg} / \mathrm{d})$ than for those fed HPC $(24.4 \mathrm{~kg} / \mathrm{d})$, HPF $(24.9 \mathrm{~kg} / \mathrm{d})$, or MPC $(24.0 \mathrm{~kg} / \mathrm{d})$ diets. Similar increases in the milk yield due to higher dietary protein have been reported in other studies with dairy cows (Barney et al., 1983; Lees et al., 1990). Responses in milk production to increased dietary protein have been attributed to the effects of protein on digestibility and DMI (Cowan et al., 1981), which is in agreement with the present experiment. Cows fed the MPF diet had the lowest numerical DMI, which probably contributed to the lower amino acid flow to the small intestine affecting the milk yield negatively. The concentrations of protein and lactose in milk were similar $(P>0.05)$ for cows fed the HP and MP diets. Similarly, Small and Gordon (1990) reported no effect of the level of protein intake on milk protein concentration. Milk 


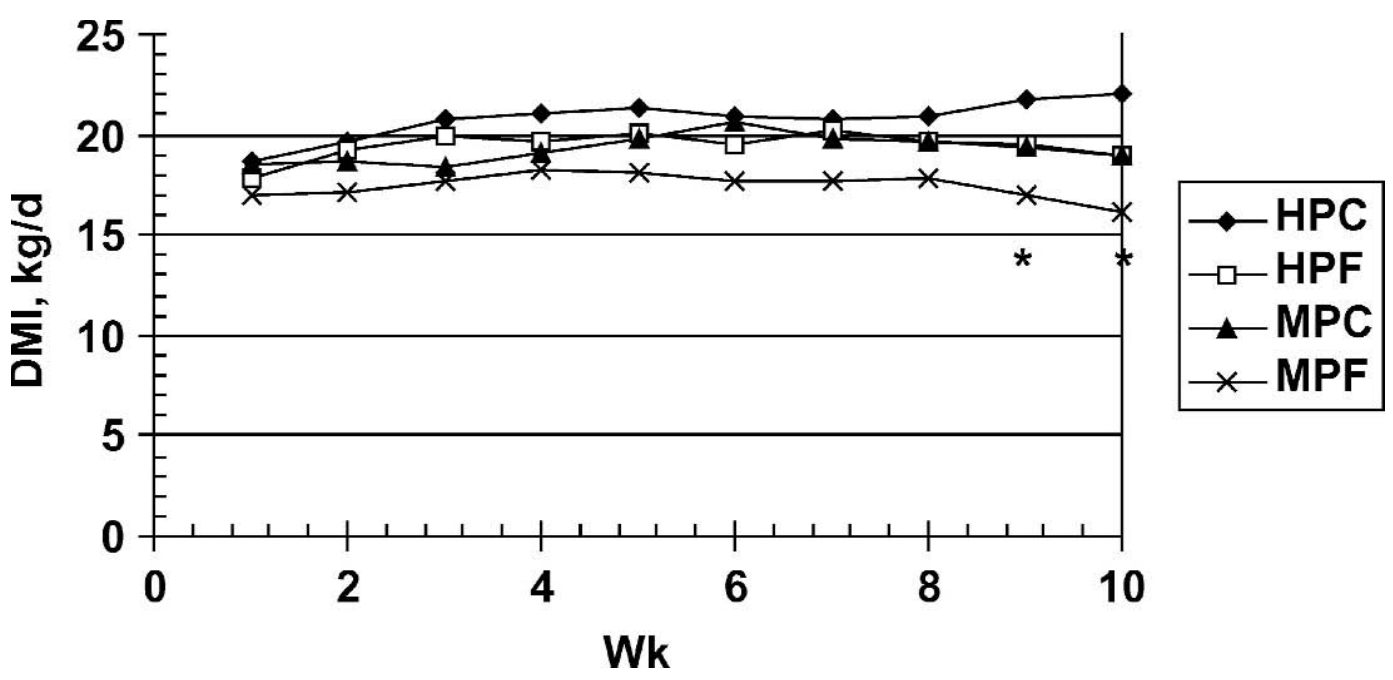

Figure 1. Dry matter intake between wk 20 and 30 of lactation of Holstein cows fed supplements based on no flaxseed (control) with $16 \%$ CP (MPC), whole flaxseed with 16\% CP (MPF), no flaxseed (control) with 18\% CP (HPC), or whole flaxseed with 18\% CP (HPF). Pooled $\mathrm{SE}=0.7$.

protein concentration was lower $(P<0.001)$ for cows fed flaxseed compared with those fed the control diets. This would agree with the results of Gonthier et al. (2004) who showed that flaxseed reduced microbial CP flow to the duodenum and microbial efficiencies (true and apparent), thus decreasing the amount of microbial protein supply for milk protein synthesis. Other work has shown that flaxseed increases milk protein concen- tration when compared with other fat sources such as sunflower seed (Petit, 2003), calcium salts of palm oil, or micronized soybeans (Petit, 2002).

Flaxseed supplementation did not affect $(P>0.1)$ milk fat concentration, which is in agreement with the previous report of Petit et al. (2002). Feeding the HP diets in the present experiment decreased $(P<0.05)$ the milk fat concentration. As milk yield was increased by feed-

Table 3. Feed intake and milk production between wk 20 and wk 30 of lactation of Holstein cows receiving 1 of 4 dietary treatments. ${ }^{1}$

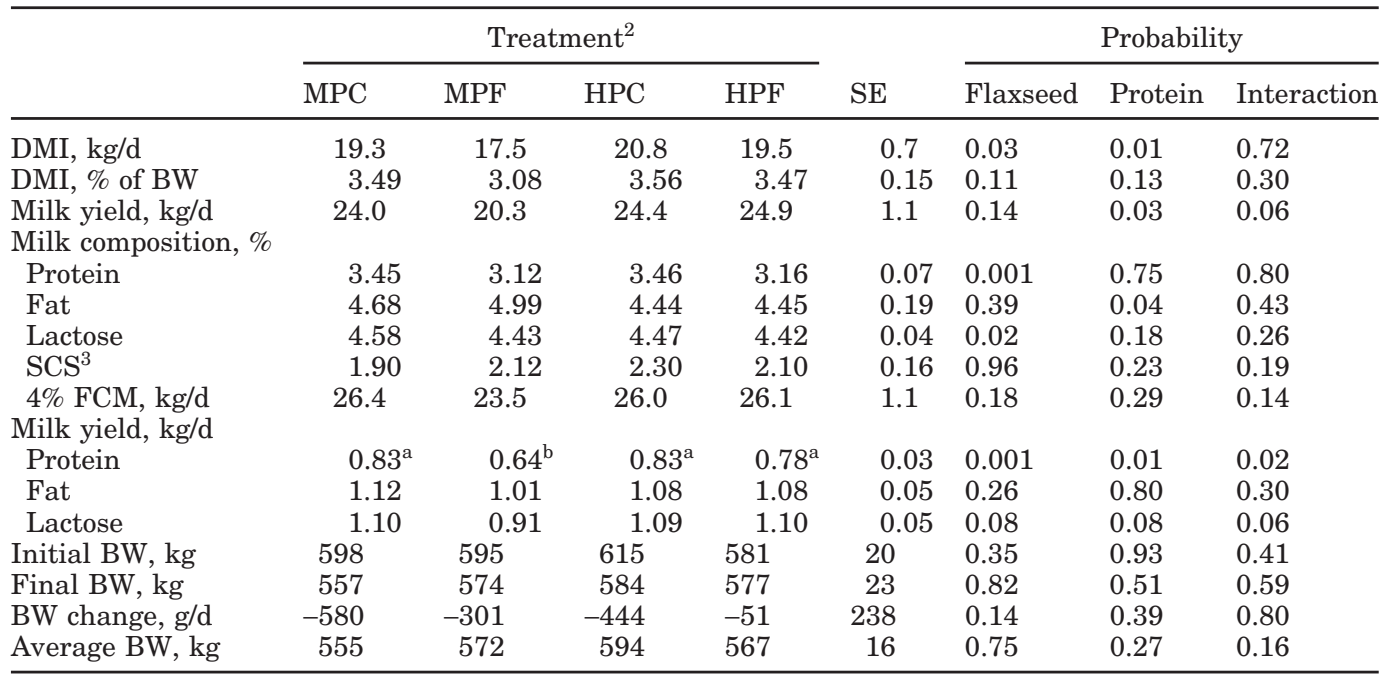

${ }^{\mathrm{a}, \mathrm{b}}$ Means within rows with different superscripts differ $(P<0.05)$.

${ }^{1}$ Least squares means with pooled SE.

${ }^{2} \mathrm{MPC}=$ Medium protein $(16 \%)$ control; $\mathrm{MPF}=$ medium protein $(16 \%)$ with flaxseed $\mathrm{HPC}=$ high protein $(18 \%)$ control; HPF $=$ high protein $(18 \%)$ with flaxseed.

${ }^{3}$ Somatic cell score $=\log _{10}$ SCC. 
ing greater concentrations of protein, the lower milk fat content may be partially explained by a dilution effect, which is a relationship usually observed with fat supplementation (Garnsworthy, 1997). Somatic cell scores and yields of $4 \%$ FCM were similar $(P>0.05)$ among treatments. There was an interaction $(P<0.05)$ between flaxseed and dietary protein concentration for milk protein yield; cows fed the MPF diet had the lowest yield of milk protein, but cows fed the other diets had similar yields of milk protein. This would agree with the results of Garnsworthy (1997), who reported that cows fed supplemental fat required a greater amount of protein to maintain milk protein yield in response to fat supplementation. These data (Garnsworthy, 1997) would suggest that cows fed flaxseed require more than $16 \%$ CP to consume enough protein to meet requirements for yields of milk and protein. Differences in feed intake among treatments could also contribute to explain the lowest yield of milk and protein for cows fed MPF. According to the NRC (2001), cows needed about $1911 \mathrm{~g}$ of metabolizable protein per day to meet requirements for milk production and composition, but cows on the MPC, MPF, HPC, and HPF diets consumed, respectively, 1636, 1774, 1879, and $1954 \mathrm{~g}$ of metabolizable protein per day (data not shown). The HPF diet would meet and the HPC diet would be close to meeting the requirement of metabolizable protein, whereas the other diets (MPC and MPF) would not. Therefore, cows fed the MPC and MPF diets consumed less than the requirements, which could partly explain why milk production was the lowest for the cows fed the MPF diet, and why cows fed the MPC diet had the greatest numerical daily BW loss. Yield of fat was similar among treatments. There was a trend $(P=0.06)$ for lower milk yield of lactose for cows fed MPF, which would be due mainly to their lowest milk yield. Dietary treatments had no effect on initial and final BW, change in BW, and average BW.

During the digestibility trial (Table 4), differences in DMI and milk yield among treatments went in the same direction as those observed for the 10-wk experiment. The digestibilities of $\mathrm{DM}, \mathrm{CP}, \mathrm{ADF}$, and NDF were lower $(P<0.01)$ for cows fed the flaxseed-supplemented diets compared with those fed the control diets. This is in agreement with the results of Petit (2002) who compared diets containing flaxseed or micronized soybeans. According to Gonthier et al. (2004), lower fiber digestion of flaxseed-based diets would result from a decrease in digestion of $\mathrm{ADF}$ (expressed as a percentage of intake) in the rumen probably due to a reduction in duodenal microbial flow. The present digestibilities of $\mathrm{DM}, \mathrm{CP}, \mathrm{ADF}$, and NDF increased $(P<0.01)$ due to higher dietary protein concentration. Similarly, Cowan et al. (1981) observed that increasing the protein con- tent of the diet increased DMI and apparent total tract digestibility. Intake of $\mathrm{N}$ during the digestion trial was greater $(P<0.05)$ by cows fed the control diets compared with cows fed the flaxseed-supplemented diets. The intake was also higher $(P<0.01)$ by cows fed the HP diets than by cows fed the MP diets. As expected, differences in $\mathrm{N}$ intake were similar to those observed for DMI. Excretion of $\mathrm{N}$ in urine was greater $(P<0.001)$ for cows fed the HP diets compared with those fed the MP diets, but there was no difference $(P>0.1)$ between cows fed the control diets and those fed the flaxseed-supplemented diets. Dietary concentration of protein had no effect $(P>0.1)$, but feeding flaxseed tended to increase $(P=0.06)$ excretion of $\mathrm{N}$ in feces. This is similar to the results previously reported by Petit (2002). Excretion of $\mathrm{N}$ in milk tended to be lower $(P=0.09)$ for cows fed the MPF diet compared with those fed the other diets, which agrees with the lowest milk protein production observed for cows fed the MPF diet during the experiment (Table 3). Retention of N, expressed either as a percentage of $\mathrm{N}$ intake or in grams per day, was lower $(P \leq 0.05)$ in cows fed the flaxseed-supplemented diets compared with those fed the control diets (Table 4), and it tended to be improved $(P=0.06$ and $P=0.08$, respectively) by feeding the HP diets compared with the MP diets.

There was no interaction $(P>0.1)$ between the week of sampling and treatment for milk fatty acid composition; therefore, results are presented as average of the wk 20 and wk 30 of lactation (Table 5). In general, feeding flaxseed decreased $(P<0.05)$ concentrations of short- and medium-chain fatty acids and increased $(P$ $<0.01$ ) those of unsaturated and long-chain fatty acids. The concentration of $\mathrm{C}_{18: 0}$ was greater $(P<0.001)$ in the milk of cows fed flaxseed than in the milk of the control cows. This is in general agreement with the results of Petit et al. (2002). A reduction in the proportion of short- and medium-chain fatty acids is typically observed following supplementation of a diet with longchain fatty acids (Grummer, 1991; Dhiman et al., 1995). According to the biohydrogenation theory of Bauman and Griinari (2003), a reduction in milk fat occurs after a shift in the milk fatty acid composition so that longer chain and unsaturated fatty acids increase in proportion, and short- and medium-chain fatty acids represent a smaller percentage of the milk fatty acid composition. Such a decrease in milk fat concentration (Table 2) when feeding flaxseed was not observed in the present experiment. It has been suggested that changes in milk fatty acid profile would involve regulation of key lipogenic enzymes in the mammary gland such as peroxisome proliferator-activated receptors with a concomitant reduction in milk fat concentration and mRNA abundance for key mammary enzymes associated with 
Table 4. Feed intake and digestibility on wk 28 of lactation of Holstein cows receiving 1 of 4 dietary treatments. ${ }^{1}$

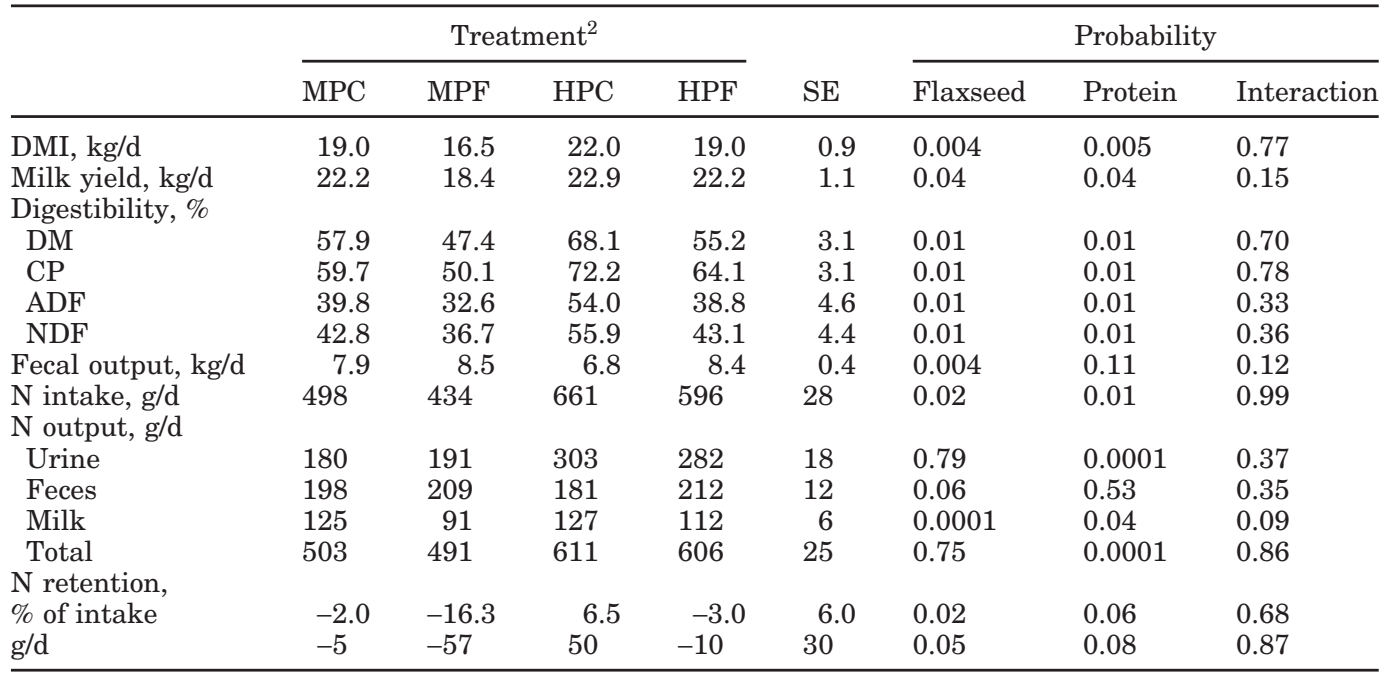

${ }^{1}$ Least square means with pooled SE.

${ }^{2} \mathrm{MPC}=$ Medium protein $(16 \%)$ control; $\mathrm{MPF}=$ medium protein $(16 \%)$ with flaxseed HPC = high protein (18\%) control; HPF = high protein $(18 \%)$ with flaxseed.

lipid synthesis (Bauman and Griinari, 2003). However, feeding flaxseed had no effect on peroxisome proliferator-activated receptors levels in the liver of dairy cows (Palin and Petit, 2004), although receptor levels were not measured in the mammary gland.

Feeding HP compared with MP diets decreased milk fat concentration and proportions of short- and medium-chain fatty acids, and increased proportions of unsaturated and long-chain fatty acids. According to the theory of Bauman and Griinari (2003), a decrease in milk fat yield corresponds to reductions of similar magnitude in mRNA abundance for genes that encoded for enzymes involved in the uptake and transport of fatty acids and de novo fatty acid synthesis through the potential control of polyunsaturated fatty acids; however, the role of protein on gene expression at the mammary level is still unknown. According to Grundy and Denke (1990), palmitic acid $\left(\mathrm{C}_{16: 0}\right)$ increases, and stearic $\left(\mathrm{C}_{18: 0}\right)$ and oleic $\left(\mathrm{C}_{18: 1}\right)$ acids decrease serum cholesterol concentration in humans, suggesting that feeding flaxseed to dairy cows would improve the fatty acid composition of milk from a human health perspective. Concentrations of conjugated linoleic acids (CLA) in the present experiment increased $(P<0.01)$ in the milk of cows fed the flaxseed-supplemented diets compared with those fed the control diets by $28 \%$. Long-chain polyunsaturated fatty acids $\left(\mathrm{C}_{18: 2}\right.$ and $\left.\mathrm{C}_{18: 3}\right)$ are subject to biohydrogenation processes in the rumen, and the intermediate steps for converting $\mathrm{C}_{18: 2}$ to CLA have been suggested by Kepler and Tove (1967). Other results (Dhiman et al., 1999) suggest that $\mathrm{C}_{18: 3}$ might be a substrate for conversion to CLA in the rumen. Although the $\mathrm{C}_{18: 3}$ fatty acids can be biohydrogenated in the rumen, they do not appear to increase the secretion of CLA into milk, as is the case with $\mathrm{C}_{18: 2}$ fatty acids (Lock and Garnsworthy, 2002). It is believed that the $\mathrm{C}_{18: 3}$ fatty acids might restrict the formation of $\mathrm{C}_{18: 1 \text { trans } 11}$, which is converted to CLA in the mammary gland (Griinari and Bauman, 1999).

The n-3 and n-6 fatty acid concentrations were greater $(P<0.001)$ and lower $(P<0.01)$, respectively, in the milk of cows fed the flaxseed-supplemented diets compared with those fed the control diets. This resulted in a lower $(P<0.001) n-6$ to n-3 fatty acid ratio in the milk of the supplemented cows. In general, feeding whole flaxseed results in the lowest n- 6 to $n-3$ fatty acid ratio in milk compared with other oilseeds (Petit, 2002, 2003; Petit et al., 2002). In comparison with the present control diets, feeding flaxseed-supplemented diets increased $(P<0.05)$ the concentrations of monounsaturated, polyunsaturated, long-chain, and unsaturated fatty acids, whereas it decreased $(P<0.05)$ those of short-chain, medium-chain, and saturated fatty acids.

The effects of increasing dietary protein concentration resulted mostly in changes in the milk fatty acid composition similar to those observed when diets were supplemented with flaxseed. However, the effects of dietary protein were of a lesser importance. Increased dietary protein decreased $(P>0.01)$ the milk concentration of the short-chain fatty acids, but did not affect $(P=0.1)$ the concentration of the medium-chain fatty acids. Concentrations of $\mathrm{C}_{6: 0}(P<0.01)$ and $\mathrm{C}_{8: 0}(P<$ 
Table 5. Average milk fatty acid composition between wk 20 and wk 30 of lactation of Holstein cows receiving 1 of 4 dietary treatments. ${ }^{1}$

\begin{tabular}{|c|c|c|c|c|c|c|c|c|}
\hline \multirow[b]{2}{*}{ Fatty acid, $\%^{3}$} & \multicolumn{4}{|c|}{ Treatment $^{2}$} & \multirow[b]{2}{*}{ SE } & \multicolumn{3}{|c|}{ Probability } \\
\hline & MPC & MPF & HPC & $\mathrm{HPF}$ & & Flaxseed & Protein & Interaction \\
\hline $6: 0$ & 3.39 & 3.41 & 2.28 & 2.42 & 0.27 & 0.75 & 0.002 & 0.83 \\
\hline $8: 0$ & 1.69 & 1.58 & 1.25 & 1.20 & 0.11 & 0.47 & 0.001 & 0.77 \\
\hline $10: 0$ & 3.29 & 2.53 & 2.97 & 2.27 & 0.20 & 0.001 & 0.13 & 0.86 \\
\hline $12: 0$ & 3.70 & 2.58 & 3.60 & 2.40 & 0.22 & 0.001 & 0.49 & 0.85 \\
\hline $13: 0$ & 0.13 & 0.07 & 0.11 & 0.06 & 0.01 & 0.001 & 0.18 & 0.99 \\
\hline $14: 0$ & 11.34 & 9.07 & 11.06 & 8.90 & 1.29 & 0.001 & 0.52 & 0.86 \\
\hline $14: 1$ cis & 1.28 & 0.79 & 1.08 & 0.90 & 0.07 & 0.001 & 0.56 & 0.04 \\
\hline 14:1 trans & 0.25 & 0.24 & 0.27 & 0.26 & 0.01 & 0.05 & 0.03 & 0.93 \\
\hline $15: 0$ & 1.52 & 1.17 & 1.43 & 1.18 & 0.05 & 0.001 & 0.49 & 0.31 \\
\hline $16: 0$ & 35.76 & 23.31 & 31.96 & 22.34 & 1.29 & 0.001 & 0.05 & 0.25 \\
\hline $16: 1 \mathrm{cis}$ & 2.08 & 1.27 & 1.76 & 1.33 & 0.12 & 0.001 & 0.22 & 0.08 \\
\hline $16: 1$ trans & 0.35 & 0.41 & 0.41 & 0.44 & 0.02 & 0.006 & 0.01 & 0.37 \\
\hline $17: 0$ & 0.83 & 0.63 & 1.11 & 0.64 & 0.12 & 0.008 & 0.23 & 0.26 \\
\hline $17: 1$ & 0.23 & 0.18 & 0.21 & 0.17 & 0.01 & 0.001 & 0.15 & 0.65 \\
\hline $18: 0$ & 8.42 & 15.68 & 11.83 & 16.14 & 1.11 & 0.001 & 0.07 & 0.16 \\
\hline 18:1 cis-11 & 0.15 & 0.37 & 0.20 & 0.42 & 0.03 & 0.001 & 0.10 & 0.97 \\
\hline $18: 1$ cis -9 & 20.05 & 30.74 & 23.46 & 32.30 & 1.42 & 0.001 & 0.07 & 0.47 \\
\hline 18:1 trans -11 & 2.01 & 2.00 & 0.93 & 2.19 & 0.90 & 0.47 & 0.61 & 0.44 \\
\hline 18:2 cis-cis & 1.75 & 1.39 & 1.85 & 1.56 & 0.08 & 0.003 & 0.09 & 0.68 \\
\hline 18:2 trans-trans & 0.12 & 0.27 & 0.23 & 0.41 & 0.04 & 0.001 & 0.006 & 0.74 \\
\hline $18: 2$ cis -9, trans -11 & 0.56 & 0.77 & 0.63 & 0.77 & 0.06 & 0.007 & 0.56 & 0.57 \\
\hline 18:3n3 & 0.54 & 1.00 & 0.67 & 1.01 & 0.05 & 0.001 & 0.09 & 0.43 \\
\hline 18:3gamma & 0.04 & 0.01 & 0.05 & 0.02 & 0.003 & 0.001 & 0.001 & 0.81 \\
\hline $20: 0$ & 0.14 & 0.27 & 0.20 & 0.31 & 0.01 & 0.001 & 0.02 & 0.52 \\
\hline $20: 1$ & 0.14 & 0.13 & 0.16 & 0.14 & 0.01 & 0.12 & 0.14 & 0.63 \\
\hline $20: 4 \mathrm{n} 6$ & 0.13 & 0.08 & 0.15 & 0.09 & 0.01 & 0.001 & 0.15 & 0.34 \\
\hline $20: 5 n 3$ & 0.04 & 0.06 & 0.06 & 0.07 & 0.01 & 0.01 & 0.01 & 0.83 \\
\hline $22: 5$ & 0.07 & 0.06 & 0.08 & 0.06 & 0.01 & 0.01 & 0.08 & 0.09 \\
\hline n3 & 0.58 & 1.02 & 0.72 & 1.08 & 0.06 & 0.001 & 0.07 & 0.45 \\
\hline n6 & 2.04 & 1.76 & 2.29 & 2.08 & 0.09 & 0.009 & 0.003 & 0.66 \\
\hline n6/n3 ratio & 3.57 & 1.79 & 3.27 & 1.93 & 0.13 & 0.001 & 0.52 & 0.07 \\
\hline MUFA & 26.55 & 36.03 & 28.48 & 38.07 & 1.53 & 0.001 & 0.17 & 0.90 \\
\hline PUFA & 3.25 & 3.61 & 3.72 & 4.00 & 0.15 & 0.02 & 0.004 & 0.75 \\
\hline SCFA & 12.22 & 10.18 & 10.23 & 8.43 & 0.69 & 0.005 & 0.006 & 0.85 \\
\hline MCFA & 53.61 & 37.07 & 49.27 & 36.16 & 1.69 & 0.001 & 0.10 & 0.28 \\
\hline LCFA & 34.17 & 52.75 & 40.50 & 55.41 & 2.13 & 0.001 & 0.03 & 0.36 \\
\hline Saturated fatty acids & 70.20 & 60.36 & 67.80 & 57.94 & 1.56 & 0.001 & 0.10 & 0.99 \\
\hline Unsaturated fatty acids & 29.94 & 39.77 & 32.36 & 42.21 & 1.57 & 0.001 & 0.10 & 0.99 \\
\hline
\end{tabular}

${ }^{1}$ Least square means with pooled SE.

${ }^{2} \mathrm{MPC}=$ Medium protein $(16 \%)$ control; $\mathrm{MPF}=$ medium protein $(16 \%)$ with flaxseed; HPC = high protein $(18 \%)$ control; HPF $=$ high protein $(18 \%)$ with flaxseed.

${ }^{3}$ MUFA = Monounsaturated fatty acids; PUFA = polyunsaturated fatty acids; SCFA = short-chain fatty acids; MCFA = medium-chain fatty acids; LCFA = long-chain fatty acids.

0.001) fatty acids were decreased by feeding greater $\mathrm{CP}$ concentrations. In general, higher dietary protein increased $(P<0.05)$ the concentrations of long-chain fatty acids in milk. As a result, concentrations of n-6 and polyunsaturated fatty acids were greater $(P<0.01)$ in the milk of cows fed $18 \%$ compared with $16 \%$ protein.

The concentrations of ammonia and total VFA in rumen fluid samples taken during wk 10 of the experiment (wk 30 of lactation) were not affected $(P>0.1)$ by flaxseed supplementation. Ammonia concentrations (mean $\pm \mathrm{SE}$ ) were $75 \pm 11.8,121 \pm 11.8,148 \pm 12.4$, and $117 \pm 12.4 \mathrm{mg} / \mathrm{L}$ for diets MPC, MPF, HPC, and HPF, respectively. Total VFA concentrations (mean $\pm \mathrm{SE}$ ) averaged $69 \pm 9.5,81 \pm 9.6,88 \pm 10.1$, and $70 \pm 10.1$ (mmol/100 mL) for diets MPC, MPF, HPC, and HPF, respectively. This would indicate that whole flaxseed did not affect the microbial population and fermentation in the rumen. Similarly, the concentrations of total protozoa or different categories of protozoa in rumen fluid on wk 0 (data not shown) and wk 10 (Table 6) were not affected $(P>0.1)$ by the dietary flaxseed. However, dietary supplementation with flaxseed oil, sunflower seed oil, or rolled sunflower seeds decreased the concentration of ammonia $\mathrm{N}$ and drastically reduced the protozoal population in the rumen of sheep (Ikwuegbu and Sutton, 1982; Ivan et al., 2001, 2003), whereas rolled sunflower seeds produced a $30 \%$ sparing effect on the requirement of the dietary protein (Ivan et al., 2004). 
Table 6. Concentration $\left(\times 10^{5} / \mathrm{mL}\right)$ of ciliate protozoa in rumen fluid of lactating Holstein cows receiving 1 of 4 dietary treatments. ${ }^{1}$

\begin{tabular}{|c|c|c|c|c|c|c|c|c|}
\hline \multirow[b]{2}{*}{ Ciliate protozoa } & \multicolumn{4}{|c|}{ Treatment $^{2}$} & \multirow[b]{2}{*}{$\mathrm{SE}$} & \multicolumn{3}{|c|}{ Probability } \\
\hline & MPC & $\mathrm{MPF}$ & $\mathrm{HPC}$ & $\mathrm{HPF}$ & & Flaxseed & Protein & Interaction \\
\hline Entodinium spp. & 3.35 & 3.59 & 4.01 & 2.59 & 0.07 & 0.28 & 0.81 & 0.45 \\
\hline Holotrich protozoa & 0.17 & 0.19 & 0.07 & 0.09 & 0.04 & 0.85 & 0.85 & 0.15 \\
\hline Cellulolytic protozoa $^{3}$ & 0.16 & 0.20 & 0.61 & 0.27 & 0.08 & 0.96 & 0.39 & 0.13 \\
\hline Total protozoa & 3.67 & 3.98 & 4.68 & 2.94 & 0.07 & 0.28 & 0.86 & 0.39 \\
\hline
\end{tabular}

To prevent ruminal biohydrogenation of linolenic acid in flaxseed and subsequent destruction of its positive effect on the dairy cow reproduction (Petit et al., 2001), whole flaxseed was used in the present experiment. Because protozoa have a limited ability to assimilate and transform dietary lipids, high dietary lipids are toxic to protozoa (Williams, 1989), causing swelling and consequent disruption of the organism (Girard and Hawke, 1978). It would appear, therefore, that there was insufficient release of the oil into the rumen fluid from the intact flaxseed for protozoal uptake and effective reduction of the rumen microfauna. Consequently, because there was no reduction in the ruminal protozoa population due to flaxseed supplementation, there was also no sparing effect on the dietary protein requirement and the excretion of $\mathrm{N}$ in urine and feces. It is well established that the ammonia $\mathrm{N}$ concentration decreases, whereas the availability of dietary amino acids for intestinal absorption increases with the reduction of protozoal population in the rumen (Veira et al., 1983; Ivan et al., 1991, 2003). The results of the present experiment show clearly that a reduction in the rumen fauna, and the associated reduction in the requirement for dietary protein and $\mathrm{N}$ excretion, probably cannot be achieved without appropriate processing (e.g., rolling) of supplemental flaxseed.

\section{CONCLUSIONS}

Although feeding whole, untreated flaxseed had no effect on $\mathrm{N}$ excretion in urine, there was a trend for greater excretion of $\mathrm{N}$ in feces of cows fed flaxseed compared with those fed no flaxseed as a result of greater fecal output for cows fed the former diet. This would suggest that feeding flaxseed has no sparing effect on $\mathrm{N}$ requirements of midlactating cows because feeding $16 \%$ compared with $18 \% \mathrm{CP}$ in a diet containing flaxseed resulted in the lowest milk yield and milk protein production. Feeding 16\% compared with $18 \% \mathrm{CP}$ in a TMR containing whole flaxseed compared with a TMR without flaxseed would have negative effects on milk production. However, when the TMR contains 18\% CP, feeding flaxseed or not would result in similar milk production.

\section{ACKNOWLEDGMENTS}

The authors thank N. Clark, L. Veilleux, S. Dallaire, and C. Barkley for technical assistance, the Atlantic Dairy and Forage Institute for conducting the experiment with dairy cows, and S. Méthot for his help in analyzing the data. The authors are pleased to acknowledge the financial contribution by the Livestock Environmental Initiative and by the Agriculture and AgriFood Canada Matching Investment Initiative (MII).

\section{REFERENCES}

Allen, M. S. 2002. Effects of diet on short-term regulation of feed intake by lactating dairy cattle. J. Dairy Sci. 83:1598-1624.

AOAC. 1990. Official Methods of Analysis. 15th ed. Association of Official Analytical Chemists, Washington, DC.

Barney, D. J., D. G. Griese, G. K. Macleoa, and L. G. Young. 1983. Response of cows to dietary crude protein during midlactation. J. Dairy Sci. 64:655-661.

Bauman, D. E., and J. M. Griinari. 2003. Nutritional regulation of milk fat synthesis. Annu. Rev. Nutr. 23:203-227.

Clark, J. H. 1975. Lactational responses to post-ruminal administration of proteins and amino acids. J. Dairy Sci. 58:1178-1197.

Cowan, R. T., G. W. Reid, J. F. D. Greenhalgh, and C. A. G. Tait. 1981. Effects of feeding level in late pregnancy and dietary protein concentration during early lactation on food intake, milk yield, live-weight change and nitrogen balance of cows. J. Dairy Res. 48:201-212.

Crawford, R. J., and W. H. Hoover. 1984. Effects of particle size and formaldehyde treatment of soybean meal on milk production and composition for dairy cows. J. Dairy Sci. 67:1945-1952.

Dhiman, T. R., G. R. Anand, L. D. Satter, and M. W. Pariza. 1999. Conjugated linoleic acid content of milk from cows fed different diets. J. Dairy Sci. 82:2146-2156.

Dhiman, T. R., K. V. Zanten, and L. D. Satter. 1995. Effect of dietary fat source on fatty acid composition of cows' milk. J. Sci. Food Agric. 69:101-107.

Garnsworthy, P. C. 1997. Fats in dairy cow diets. Pages 87-13 in Recent Advances in Animal Nutrition. P. C. Garnsworthy and D. J. A. Cole, ed. University of Nottingham Press, Nottingham, UK. 
Girard, V., and J. C. Hawke. 1978. The role of Holotrichs in the metabolism of dietary linoleic acid in the rumen. Biochim. Biophys. Acta 528:17-27.

Gonthier, C., A. F. Mustafa, R. Berthiaume, H. V. Petit, R. Martineau, and D. R. Ouellet. 2004. Effects of feeding micronized and extruded flaxseed on ruminal fermentation and nutrient utilization by dairy cows. J. Dairy Sci. 87:1854-1863.

Griinari, J. M., and D. E. Bauman. 1999. Biosynthesis of conjugated linoleic acid and its incorporation into meat and milk in ruminants. Pages 180-200 in Advances in Conjugated Linoleic Acid Research. Volume 1. M. P. Yurawecz, M. M. Mossaba, J. K. G. Kramer, M. W. Pariza, and G. J. Nelson, ed. AOCS Press, Champaign, IL.

Grummer, R. R. 1991. Effect of feed on the composition of milk fat. J. Dairy Sci. 74:3244-3257.

Grundy, S. M., and M. A. Denke. 1990. Dietary influences on serum lipids and lipoproteins. J. Lipid Res. 31:1149-1161.

Ikwuegbu, O. A., and J. D. Sutton. 1982. The effect of varying the amount of linseed oil supplementation on rumen metabolism in sheep. Br. J. Nutr. 48:365-375.

Ivan, M., T. Entz, P. S. Mir, Z. Mir, and T. A. McAllister. 2003. Effects of sunflower seed supplementation and different dietary protein concentrations on the ciliate protozoa population dynamics in the rumen of sheep. Can. J. Anim. Sci. 83:809-817.

Ivan, M., M. Hidiroglou, and H. V. Petit. 1991. Duodenal flow of nitrogen following protozoal inoculation of fauna-free sheep fed a diet supplemented with casein or soybean meal. Can. J. Anim. Sci. 71:793-801.

Ivan, M., P. S. Mir, K. M. Koenig, L. M. Rode, L. Neill, T. Entz, and Z. Mir. 2001. Effects of dietary sunflower oil on rumen protozoa population and tissue concentration of conjugated linoleic acid in sheep. Small Rumin. Res. 41:215-227.

Ivan, M., P. S. Mir, Z. Mir, T. Entz, M. L. He, and T. A. McAllister. 2004. Effects of dietary sunflower seeds on rumen protozoa and growth of lambs. Br. J. Nutr. 92:303-310.

Jiang, J., L. Bjoerck, R. Fonden, and M. Emanuelson. 1996. Occurrence of conjugated cis-9, trans-11 octadecanoic acid in bovine milk: Effects of feed and dietary regimen. J. Dairy Sci. 79:438445.

Kepler, C. R., and S. B. Tove. 1967. Biohydrogenation of unsaturated fatty acids. J. Biol. Chem. 242:5686-5692.

Lees, J. A., J. D. Olsham, W. Haresign, and P. C. Garnsworthy. 1990. The effect of patterns of rumen fermentation on the response by dairy cows to dietary protein concentration. Br. J. Nutr. 63:177-186.

Lock, A. L., and P. C. Garnsworthy. 2002. Independent effects of dietary linoleic and linolenic fatty acids on the conjugated linoleic acid content of cows' milk. Anim. Sci. 74:163-176.

Mir, P. S., G. J. Mears, E. K. Okine, T. Entz, C. M. Ross, S. D. Husar, and Z. Mir. 2000. Effects of increasing dietary grain on viscosity of duodenal digesta and plasma hormone, glucose and amino acid concentrations in steers. Can. J. Anim. Sci. 80:703-712.

Moate, P. J. 1989. Defaunation increases milk yield of dairy cows. Page 18A in Recent Advances in Animal Nutrition in Australia.
D. J. Farrell, ed. University of New England Printery, Armidale, NSW, Australia.

National Research Council. 2001. Nutrient Requirements of Dairy Cattle. 7th rev. ed. Natl. Acad. Press, Washington, DC.

Ogimoto, K., and S. Imai. 1981. Atlas of Rumen Microbiology. Japan Scientific Societies Press, Tokyo, Japan.

Onetti, S. G., and R. R. Grummer. 2004. Response of lactating cows to three supplemental fat sources as affected by forage in the diet and stage of lactation: A meta-analysis of literature. Anim. Feed Sci. Technol. 115:65-82.

Palin, M. F., and H. V. Petit. 2004. Effects of polyunsaturated fatty acids on hepatic PPAR $\alpha$ mRNA levels in the transition cow. J. Anim. Feed Sci. 13(Suppl. 1):445-448.

Petit, H. V. 2002. Digestion, milk production, milk composition, and blood composition of dairy cows fed whole flaxseed. J. Dairy Sci. 85:1482-1490.

Petit, H. V. 2003. Digestion, milk production, milk composition, and blood composition of dairy cows fed formaldehyde treated flaxseed or sunflower seed. J. Dairy Sci. 86:2637-2646.

Petit, H. V., R. J. Dewhurst, J. G. Proulx, M. Khalid, W. Haresign, and $\mathrm{H}$. Twagiramungu. 2001. Milk production, milk composition, and reproductive function of dairy cows fed different fats. Can. J. Anim. Sci 81:263-271.

Petit, H. V., R. J. Dewhurst, N. D. Scollan, J. G. Proulx, M. Khalid, W. Haresign, H. Twagiramungu, and G. E. Mann. 2002. Milk production and composition, ovarian function, and prostaglandin secretion of dairy cows fed omega-3 fats. J. Dairy Sci. 85:889-899.

SAS Institute. 2000. SAS (Statistical Analysis System), release 8.02. SAS Institute, Inc., Cary, NC.

Satter, L. D. 1986. Protein supply from undegraded dietary protein. J. Dairy Sci. 69:2734-2749.

Small, J. D., and F. J. Gordon. 1990. A comparison of the responses by lactating cows given grass silage to changes in the degradability or quantity of protein offered in the supplement. Anim. Prod. 50:391-398

Van Soest, P. J., J. B. Robertson, and B. A. Lewis. 1991. Methods for dietary fiber, neutral detergent fiber, and nonstarch polysaccharides in relation to animal nutrition. J. Dairy Sci. 74:35833597.

Veira, D. M., M. Ivan, and P. Y. Jui. 1983. Rumen ciliate protozoa: Effects on digestion in the stomach of sheep. J. Dairy Sci. $66: 1015-1022$.

Vérité, R., and M. Journet. 1977. Utilization of formaldehyde treated oil-meals by dairy cows. II. Milk production as affected by oilmeal treatment and protein supply during early lactation. Ann. Zootech. 26:183-205.

Weatherburn, M. W. 1967. Phenol-hypochlorite reaction for determination of ammonia. Anal. Chem. 39:971-974.

Williams, A. G. 1989. Metabolic activities of rumen protozoa. Pages 97-126 in The Roles of Protozoa and Fungi in Ruminant Digestion. J. V. Nolan, R. A. Leng, and D. I. Demeyer, ed. Penambul Books, Armidale, NSW, Australia.

Wright, T., B. McBride, and B. Holub. 1998. Docosahexaenoic acidenriched milk. World Rev. Nutr. Diet. 83:160-165. 